J Pediatr. 2012 February ; 160(2): 297-302. doi:10.1016/j.jpeds.2011.08.011.

\title{
Disease Activity, Proteinuria, and Vitamin D Status in Children with Systemic Lupus Erythematosus and Juvenile Dermatomyositis
}

\author{
Angela Byun Robinson, MD, MPH ${ }^{1}$, Myrtle Thierry-Palmer, PhD $^{2}$, Keisha L. Gibson, MD, \\ $\mathrm{MPH}^{3}$, and C. Egla Rabinovich, MD, $\mathrm{MPH}^{4}$ \\ ${ }^{1}$ Division of Pediatric Rheumatology, Rainbow Babies and Children's Hospital, Cleveland, Ohio \\ ${ }^{2}$ Department of Microbiology, Biochemistry and Immunology, Morehouse School of Medicine \\ ${ }^{3}$ Division of Nephrology and Hypertension, University of North Carolina at Chapel Hill \\ ${ }^{4}$ Division of Pediatric Rheumatology, Duke University Medical Center
}

\section{Abstract}

Objective-To evaluate relationships between vitamin D, proteinuria, and disease activity in pediatric systemic lupus erythematosus (SLE) and juvenile dermatomyositis (JDM).

\begin{abstract}
Study design-Multiple linear regression was used to associate subject-reported race, sunscreen use, and vitamin D intake with physician-assessed disease activity and serum 25-hydroxyvitamin $\mathrm{D}[25(\mathrm{OH}) \mathrm{D}]$ in subjects with pediatric SLE $(\mathrm{n}=37)$ or JDM $(\mathrm{n}=21)$. Serum $25(\mathrm{OH}) \mathrm{D}$ was correlated with urinary vitamin D binding protein/creatinine ratio (DBP/C) and other indicators of proteinuria.
\end{abstract}

Results-Serum 25(OH)D levels in subjects with SLE were inversely associated with the natural $\log$ of urinary DBP/C $(r=-0.63, \mathrm{p}<0.001)$ and urine protein to creatinine ratio $(\mathrm{r}=-0.60$, $\mathrm{p}<0.001$ ), with an adjusted mean $10.9(95 \%$ CI 5.1, 16.8) $\mathrm{ng} / \mathrm{mL}$ decrease in 25(OH)D for those with proteinuria. Excluding subjects with proteinuria, serum 25(OH)D levels were inversely associated with disease activity in JDM, but not in SLE. Overall, 66\% of all subjects were taking concurrent corticosteroids, but this was not associated with $25(\mathrm{OH}) \mathrm{D}$ levels.

Conclusions-Low serum 25(OH)D in patients with SLE is associated with proteinuria and urinary DBP. Vitamin D deficiency is associated with disease activity in patients with JDM and SLE; this relationship in SLE may be confounded by proteinuria.

\section{Key Indexing Terms}

25-hydroxyvitamin D; vitamin D binding protein

(C) 2011 Mosby, Inc. All rights reserved.

Corresponding author and reprint requests: Angela Byun Robinson, MD, MPH, Assistant Professor, Pediatric Rheumatology, Rainbow Babies and Children's Hospital MS 6008B, 11100 Euclid Avenue, Cleveland, OH 44106, Phone: 216-844-3645, Fax: 216-844-7587, angela.robinson@uhhospitals.org.

Publisher's Disclaimer: This is a PDF file of an unedited manuscript that has been accepted for publication. As a service to our customers we are providing this early version of the manuscript. The manuscript will undergo copyediting, typesetting, and review of the resulting proof before it is published in its final citable form. Please note that during the production process errors may be discovered which could affect the content, and all legal disclaimers that apply to the journal pertain.

The authors declare no conflicts of interest. 
Beyond its skeletal effects, vitamin $\mathrm{D}$ has been recognized as an immunomodulator with effects on antigen-presenting cells. Vitamin D deficiency is associated with darker skin tone, winter season, northern latitude, age, and female sex. ${ }^{1}$ Low 25 -hydroxyvitamin D [25(OH)D] levels have been associated with increased odds of multiple sclerosis, Crohn's disease and rheumatoid arthritis, in retrospective epidemiologic studies. ${ }^{1}$ Vitamin D deficiency has also been associated with measures of cardiovascular risk, including body mass index, hypertension, and hyperglycemia. ${ }^{2}$ In adults, the optimal level of $25(\mathrm{OH}) \mathrm{D}$ for improved skeletal outcomes has been suggested to be $\geq 30 \mathrm{ng} / \mathrm{mL}$, but it is not yet known whether this level is optimal for other outcomes. ${ }^{1,3}$ Optimal levels in children are not well established. As many as $70 \%$ of American children may have $25(\mathrm{OH}) \mathrm{D}$ levels $<30 \mathrm{ng} / \mathrm{mL}{ }^{4}$

Hydroxylation of 25(OH)D to the active form, 1,25-dihdroxyvitamin D, occurs in the kidney, but also locally in cells of the immune system. In vitro, 1,25-dihydroxyvitamin D prevents differentiation of dendritic cells and modulates $\mathrm{T}$ cell phenotype and function. ${ }^{5}$ 1,25-dihydroxyvitamin $\mathrm{D}$ may inhibit $\mathrm{T}$ cell proliferation and cytokine production, inhibit proliferation of activated B cells, and impair generation of plasma cells ${ }^{67}$ Differentiation of dendritic cells and the resultant production of type I interferon may be important in the pathogenesis of systemic lupus erythematosus (SLE). ${ }^{8}$

Animal models have shown that vitamin D and calcium supplementation can inhibit lupus activity. ${ }^{9,10}$ There have been incidental findings of an association between vitamin D deficiency and SLE nephritis, ${ }^{11}$ but studies evaluating this relationship are lacking. There have been no correlations in subjects with SLE between vitamin D status and direct or indirect measures of proteinuria, such as spot urine protein to creatinine (UP/C) ratio or serum albumin.

Juvenile dermatomyositis (JDM) is a photosensitive rheumatic disease, treated commonly with sun avoidance, corticosteroids, methotrexate and hydroxychloroquine. JDM shares many similarities with pediatric SLE in photosensitivity and methods of treatment, but is not associated with proteinuria, making this an ideal comparison group for SLE. Studies specifically evaluating the relationship between vitamin $\mathrm{D}$ levels and disease activity in JDM have not been reported. Given the lack of information on vitamin D status in JDM, we chose to evaluate serum vitamin D levels and associated risk factors in this population to increase the information known on vitamin D status in pediatric rheumatic diseases.

The objectives of this prospective cohort study are to determine whether low levels of $25(\mathrm{OH}) \mathrm{D}$ are associated with proteinuria and assess the relationship between vitamin D deficiency and disease activity in two photosensitive autoimmune conditions (SLE and JDM).

\section{Methods}

Children and adolescents with SLE or JDM prior to the age of 18 were eligible. Subjects were excluded if they were pregnant, were taking bisphosphonates, had received organ transplantation, or were taking greater than 1,000 IU daily supplemental vitamin D in the past 3 months. All patients who met these criteria and were seen in the Duke Pediatric Rheumatology Clinic, Duke Lupus Clinic, or University of North Carolina Pediatric Nephrology Clinic were prospectively approached for recruitment between May 2009 and March 2010. The diagnosis of SLE was confirmed using the revised American College of Rheumatology criteria, ${ }^{12}$ and JDM was confirmed using Bohan and Peter criteria. ${ }^{13}$ The Institutional Review Boards of Duke University Medical Center and the University of North Carolina at Chapel Hill approved the protocol. 
Informed consent was obtained from the young adults and the parents or guardians of those younger than 18 years of age, from whom assent was obtained.

\section{Disease and subject characteristics and medication exposures}

All SLE or JDM clinical manifestations and medication exposures were documented by medical record abstraction. Dietary information on vitamin D intake was obtained using an adult food frequency questionnaire previously validated against 7-day food diaries by Blalock et al. ${ }^{14}$ No short validated questionnaires regarding calcium and vitamin D intake were available for children at the time of this study. Sunscreen usage, vitamin D supplement intake, and race/ethnicity were obtained by standardized questionnaire. No information was collected on sun exposure. Doses of vitamin D supplementation were checked against the medical record by the primary investigator when subjects reported taking supplementation but could not recall the dose. Disease activity at the time of the study visit was assessed by the medical provider using a Physician's Global Assessment (PGA) by $10 \mathrm{~cm}$ visual analogue scale in all subjects and Systemic Lupus Erythematosus Disease Activity Index (SLEDAI) in subjects with SLE. ${ }^{15}$

\section{Renal disease}

Serum albumin and UP/C ratios were measured at individual institutions. Proteinuria was defined as a UP/C ratio greater than or equal to 0.5 . SLE nephritis was defined by histopathological pattern on renal biopsy according to the 2003 ISN/RPS classification system. ${ }^{16}$ Estimated glomerular filtration rates (eGFR) were calculated based on height and serum creatinine using the classical Schwartz formula. ${ }^{17}$

\section{Vitamin D binding protein and vitamin D metabolite analysis}

Serum 25(OH)D concentrations were analyzed using tandem mass spectroscopy available from Mayo Laboratories. Urinary DBP in $\mathrm{ng} / \mathrm{dL}$ was measured with a vitamin $\mathrm{D}$ binding protein EIA kit (ALPCO Diagnostics, Salem, NH), and standardized against concurrent urinary creatinine measurements in $\mathrm{mg} / \mathrm{dL}$. Urinary vitamin $\mathrm{D}$ metabolite content was measured according to previously published methods. ${ }^{18}$ The procedure involved concentration of $10 \mathrm{~mL}$ of urine to $3 \mathrm{~mL}$ using centriprep-30 concentrators (Amicon Inc, Beverly, MA). The concentrated samples were subjected to a modified dichloromethanemethanol liquid-liquid extraction followed by solid-phase separation on silica cartridges. The first two fractions from the solid phase extraction (containing 25(OH)D and 24,25dihydroxyvitamin $\mathrm{D}$ ) were combined and assayed by radioimmunoassay kits (12\% intraassay CV) for 25(OH)D (Diasorin, Stillwater, MN). Samples were measured in duplicate.

\section{Statistical analysis}

Analyses were performed using STATA 10.0 (StataCorp., College Station, TX). Two-sided tests of hypotheses were used; p-values less than 0.05 were considered statistically significant. Differences in means were assessed using Student t-test. Differences in proportions were assessed using chi-square or Fisher exact test, where appropriate. Correlation between serum 25(OH)D levels and urinary DBP/C was obtained using pairwise correlation. Multivariable linear regression was used to determine differences in $25(\mathrm{OH}) \mathrm{D}$ levels in subjects with and without proteinuria, adjusting for disease type, race, disease activity, sunscreen usage, and dietary/supplement intake.

\section{Results}

There were 58 subjects age 4 to 21 years included in our study; 21 subjects with JDM and 37 subjects with SLE. Demographic and baseline characteristics of disease activity are 
provided in Table I. There was no significant difference in prevalence of obesity, mean prednisone dose, percentage taking hydroxychloroquine, percentage using sunscreen regularly, intake of vitamin D supplements, or dietary intake of vitamin D between patients with SLE and JDM.

Among those with SLE, all subjects with proteinuria had documented renal biopsies with glomerulonephritis between class III and V. Roughly half of subjects with SLE without proteinuria had a history of proliferative nephritis. Three subjects with proteinuria had estimated glomerular filtration rates below $75 \mathrm{ml} / \mathrm{min} / 1.73 \mathrm{~m}^{2}$. Subjects with proteinuria had lower serum albumin levels.

\section{Serum 25(OH)D, proteinuria, and urinary DBP/C}

Serum 25(OH)D levels indicated high prevalence of levels below $30 \mathrm{ng} / \mathrm{mL}$ among all three groups; proteinuria was associated with a mean $13 \mathrm{ng} / \mathrm{mL}$ decrease in vitamin D level among subjects with SLE (Table I). Subjects with proteinuria had 19.7 times increased odds of levels $\leq 10 \mathrm{ng} / \mathrm{mL}$ (95\% CI 1.8 to 944.5). Serum 25(OH)D levels in subjects with SLE were inversely associated with the UP/C ratio $(\mathrm{r}=-0.67, \mathrm{p}<0.001)$ and urinary DBP/C $(\mathrm{r}=$ $-0.59, \mathrm{p}<0.001)$ and directly associated with serum albumin (Figure). Serum $25(\mathrm{OH}) \mathrm{D}$ levels in subjects with JDM were not associated with UP/C ratio, urinary DBP/C, or serum albumin. Pair wise association and linear regression using the natural log of the UP/C and $\mathrm{DBP} / \mathrm{C}$ ratios improved model fit, but did not change the interpretation. (Figure and Table II). Urinary DBP/C and $25(\mathrm{OH}) \mathrm{D} / \mathrm{C}$ values were highly variable, although mean DBP/C was highest in the urine of subjects with SLE and proteinuria. (Table I). Vitamin D metabolite content in the urine of subjects with SLE and proteinuria tended to be either high or very low.

\section{Evaluation of vitamin D by risk factors}

Using analysis of variance or simple regression, vitamin D status was not associated with age, obesity, dietary intake of vitamin $\mathrm{D}$, history of photosensitivity, current rash, or duration of disease. Higher serum 25(OH)D levels were associated with white race, JDM compared with SLE, and lower disease activity by PGA. Vitamin D supplementation (800 IU daily) was associated with a mean $10.0(95 \%$ CI $3.2,16.8) \mathrm{ng} / \mathrm{mL}$ increase in $25(\mathrm{OH}) \mathrm{D}$ level compared with non-supplementation. Regular use of sunscreen was associated with a 6 $\mathrm{ng} / \mathrm{mL}$ increase in $25(\mathrm{OH}) \mathrm{D}$, although regular sunscreen users were also more likely to take vitamin D supplements.

Among subjects with SLE, lower vitamin D status was significantly associated with increased SLEDAI, PGA, and presence of class III or higher glomerulonephritis. Because all subjects with severe vitamin D deficiency had renal disease, an odds ratio for renal disease and severe vitamin D deficiency could not be calculated.

\section{Multivariate analysis}

Among subjects with SLE, after adjusting for white race and use of supplements, disease activity by PGA or SLEDAI and proteinuria were all independently and inversely associated with serum 25(OH)D levels (Table II and Figure). There did not appear to be any significant interaction between proteinuria and race, use of supplements, or disease activity. There was co-linearity between the presence of proteinuria and increasing PGA and SLEDAI. When subjects with proteinuria were excluded, increased PGA and SLEDAI were no longer associated with decreased serum $25(\mathrm{OH}) \mathrm{D}$ levels. In these models, proteinuria was associated with a $10.9 \mathrm{ng} / \mathrm{mL}$ (95\% CI 5.1 to $16.8 \mathrm{ng} / \mathrm{mL}$ ) decrease in vitamin D level. 
After adjusting for known influences on vitamin D status (race and use of vitamin D supplements), increasing disease activity by PGA was associated with decreasing $25(\mathrm{OH}) \mathrm{D}$ levels among subjects with JDM. Current active rash was not significantly associated with serum 25(OH)D levels in these subjects. For subjects with JDM, each $400 \mathrm{IU}$ of daily vitamin D supplementation was associated with a mean increase in $25(\mathrm{OH}) \mathrm{D}$ of $6.5 \mathrm{ng} / \mathrm{mL}$ (95\% CI 1.3 to 11.7). Each $1 \mathrm{~cm}$ increase in PGA was associated with a mean decrease in serum $25(\mathrm{OH}) \mathrm{D}$ of $1.7 \mathrm{ng} / \mathrm{mL}$ ( $95 \%$ CI 0.3 to $3.1 \mathrm{ng} / \mathrm{mL}$ ). Increased prednisone dosage was not associated with vitamin D levels after adjustment for race and vitamin D supplementation.

\section{Discussion}

We demonstrate here an inverse relationship between serum 25(OH)D levels and proteinuria in subjects with SLE. Several studies have shown high rates of vitamin D deficiency in subjects with SLE, associated with measures of disease activity (including renal disease) and cardiovascular risk. ${ }^{11,19,20,21,22}$ In a prior retrospective chart review of subjects with pediatric SLE at our institution, we reported an association between proliferative SLE glomerulonephritis and vitamin D deficiency (OR 11.7, 95\% CI 1.5, 89.3), and an average $10 \mathrm{ng} / \mathrm{mL}$ difference in serum $25(\mathrm{OH}) \mathrm{D}$ between subjects with and without nephritis. ${ }^{23} \mathrm{We}$ did not have statistical power to adjust for possible confounding factors. We suggest that previously reported associations between measures of disease activity and vitamin D status in SLE may be confounded by an unrecognized association between proteinuria and increased disease activity.

Serum 25(OH)D levels in subjects with JDM appear to be associated with disease activity and to be similar to that of subjects with SLE without proteinuria. One prior study has reported no significant difference in 25(OH)D levels among children with high and low disease activity in JDM; however, this was a subgroup of a larger study and was underpowered for subgroup analysis $(\mathrm{n}=13){ }^{24}$ There was a mean $7 \mathrm{ng} / \mathrm{mL}$ decrease in 25(OH)D among children with high disease activity; however, this was not statistically significant.

Prior studies have associated proteinuria and nephrotic syndrome with 25(OH)D deficiency, regardless of renal insufficiency. ${ }^{25,26,27,28,29}$ Urinary losses of $25(\mathrm{OH}) \mathrm{D}$ and vitamin D binding protein (DBP) in the urine, by competitive binding assay, in patients and animals with nephritic syndrome have been reported. ${ }^{28,30,31}$ Despite this, urinary loss of vitamin D is not well recognized as a potential explanation for vitamin D deficiency.

Thierry-Palmer et al have demonstrated vitamin D metabolites and vitamin D binding activity in the urine of normal female black and white adolescents. ${ }^{18}$ The findings in this study of an inverse relationship between serum 25(OH)D levels and urinary DBP/C and the negative correlation between serum 25(OH)D levels and UP/C suggest loss of protein-bound vitamin D metabolites as one factor for low vitamin D status in pediatric lupus patients. It is possible that part of the vitamin D deficiency associated with lupus activity may be confounded by an underlying association between proteinuria and low 25(OH)D levels as well as proteinuria and increasing measures of disease activity. In the SLE disease activity index, proteinuria, hematuria, and active renal sediment each account for 4 points on the activity score.

The DBP-25(OH)D complex is filtered through the proximal tubule cells of the kidney, where it is reabsorbed by an endocytic process governed by two carrier proteins, cubilin and megalin. ${ }^{32,33,34}$ Megalin antibodies (anti-LRP2) have been described in patients with SLE and other rheumatic diseases, ${ }^{35}$ and megalin knockout mice exhibit low molecular weight 
proteinuria and severe vitamin D deficiency. ${ }^{36} \mathrm{DBP}$ itself is genetically similar to albumin and highly complexed to $25(\mathrm{OH}) \mathrm{D}$. Loss of DBP can decrease the half-life of $25(\mathrm{OH}) \mathrm{D}$ in serum. ${ }^{37}$ In this study, the high or very low $25(\mathrm{OH}) \mathrm{D}$ content in urine of subjects with proteinuria may be explained by urinary $25(\mathrm{OH}) \mathrm{D}$ content being dependent on both urinary DBP and on serum 25(OH)D. Low serum 25(OH)D levels would decrease the amount of $25(\mathrm{OH}) \mathrm{D}$ bound to the DBP that is spilled into urine. In a previous study, urinary $25(\mathrm{OH}) \mathrm{D}$ levels did not correlate well with urinary vitamin D binding activity (indicative of urinary DBP) of healthy adolescent girls. ${ }^{18}$ DBP loss into urine may simply reflect the magnitude of proteinuria exhibited by these patients, but it is not known whether anti-megalin antibodies, leading to DBP loss and low vitamin D levels, play a part in the pathogenesis of renal disease in patients with SLE. More studies are needed on the relationship between megalin, megalin antibodies, and urinary DBP in subjects with SLE and other proteinuric diseases.

Supplementation with vitamin D at currently recommended levels (400 IU/day) increased the mean serum 25(OH)D level, but many subjects had low vitamin D levels despite supplementation. We suspect that much higher levels of vitamin D supplementation are required to maintain optimal serum $25(\mathrm{OH}) \mathrm{D}$ levels, especially in those patients with proteinuria or active disease. It is unknown what effect vitamin D deficiency has on cardiovascular risk and skeletal outcomes in these patients, although vitamin D deficiency in healthy individuals and adults with SLE have been associated with increasing cardiovascular risk.

There are several limitations of this study. We were unable to adjust for season because this study took place over 10 months of recruitment. We did not have sufficient power to examine risk factors which may have had a more subtle impact on vitamin D levels - body mass index, sunscreen use and vitamin D dietary intake. Nevertheless, from estimation of dietary levels of vitamin $\mathrm{D}$ intake by food frequency questionnaire, most of our subjects do not eat sufficient quantities of vitamin D-containing foods to ensure adequate intake of vitamin D. Although there were three subjects with eGFR below $75 \mathrm{ml} / \mathrm{min} / 1.73 \mathrm{~m}^{2}$ (between 50 and $60 \mathrm{ml} / \mathrm{min} / 1.73 \mathrm{~m}^{2}$ ), lower eGFR levels were not associated with lower levels of serum $25(\mathrm{OH}) \mathrm{D}$ in this cohort. Impaired renal function is known to affect hydroxylation of 25(OH)D to 1,25-dihydroxyvitamin $\mathrm{D}$, but should not impact the serum levels of 25(OH)D.

A strength of this study is an enriched sample of subjects with renal disease, allowing for a closer look at the relationship between proteinuria and vitamin D deficiency. This study was also strengthened by information on dietary history and sunscreen usage in subjects with rheumatic disease, multiple assessments of disease activity in subjects with SLE, and multiple assessments of proteinuria and renal disease (spot urine protein to creatinine ratio, serum albumin, urinary DBP, and renal biopsy information).

\section{Acknowledgments}

The authors would like to acknowledge the following individuals for advice and technical support: Charles Poole, David Pisetsky, Laura Schanberg, Heather Van Mater, Megan Clowse, Lisa Criscione-Schreiber, Eveline Wu, Janet Wootton, Lindsey Franks, Jennifer Stout, and Rasheed Gbadagesin of Duke University; Stacy Cephas and Rabeeh El-Refadi of Morehouse School of Medicine.

Supported by a grant from the National Institutes of Health T32 training grant and Duke Children's Miracle Network.

\section{References}

1. Holick MF. Vitamin D deficiency. N Engl J Med. 2007; 357:266-281. [PubMed: 17634462] 
2. Reis JP, von Muhlen D, Miller ER, Michos ED, Appel LJ. Vitamin D status and cardiometabolic risk factors in the United States adolescent population. Pediatrics. 2009; 124:e371-e379. [PubMed: 19661053]

3. Bischoff-Ferrari HA, Giovannucci E, Willett WC, Dietrich T, Dawson-Hughes B. Estimation of optimal serum concentrations of 25-hydroxyvitamin D for multiple health outcomes. Am J Clin Nutr. 2006; 84:18-28. [PubMed: 16825677]

4. Kumar J, Muntner P, Kaskel FJ, Hailpern SM, Melamed ML. Prevalence and association of 25hydroxyvitamin D deficiency in US children: NHANES 2001-2004. Pediatrics. 2009; 124:e362e370. [PubMed: 19661054]

5. Penna G, Adorini L. 1 Alpha, 25-dihydroxyvitamin $\mathrm{D}_{3}$ inhibits differentiation, maturation, activation, and survival of dendritic cells leading to impaired alloreactive $\mathrm{T}$ cell activation. $\mathrm{J}$ Immunol. 2000; 164:2405-2411. [PubMed: 10679076]

6. Chen S, Sims GP, Chen XX, Gu YY, Chen S, Lipsky PE. Modulatory effects of 1,25dihydroxyvitamin $\mathrm{D}_{3}$ on human B cell differentiation. J Immunol. 2007; 179:1634-1637. [PubMed: 17641030]

7. VanHalteren AG, Tysma OM, VanEtten E, Mathieu C, Roep BO. 1alpha, 25-dihydroxyvitamin $\mathrm{D}_{3}$ or analogue treated dentritic cells modulate human autoreactive $\mathrm{T}$ cells via the selective induction of apoptosis. J Autoimmun. 2004; 23:233-239. [PubMed: 15501394]

8. Rönnblom L, Pascual V. The innate immune system in SLE: type I interferons and dendritic cells. Lupus. 2008; 17:394-399. [PubMed: 18490415]

9. Abe J, Nakamura K, Takita Y, Nakano T, Irie H, Nishii Y. Prevention of immunological disorders in MRL/l mice by a new synthetic analogue of vitamin D3: 22-oxa-1 alpha, 25-dihydroxyvitamin D3. J Nutr Sci Vitaminol (Tokyo). 1990; 36:21-31. [PubMed: 2163440]

10. Lemire JM, Ince A, Takashima M. 1,25-dihydroxyvitamin $D_{3}$ attenuates the expression of experimental murine lupus of MRL/l mice. Autoimmunity. 1992; 12:143-148. [PubMed: 1617111]

11. Kamen DL, Cooper GS, Bouali H, Shaftman SR, Hollis BW, Gilkeson GS. Vitamin D deficiency in systemic lupus erythematosus. Autoimmunity Rev. 2006; 5:114-117. [PubMed: 16431339]

12. Hochberg MC. Diagnostic and Therapeutic Criteria Committee of the American College of Rheumatology. Updating the American College of Rheumatology revised criteria for the classification of systemic lupus erythematosus. Arthritis Rheum. 1997; 40:1725. [PubMed: 9324032]

13. Bohan A, Peter JB. Polymyositis and dermatomyositis. Part I. N Engl J Med. 1975; 292:344-347.

14. Blalock SJ, Norton LL, Patel RA, Cabral K, Thomas CL. Development and assessment of a short instrument for assessing dietary intakes of calcium and vitamin D. J Am Pharm Assoc. 2003; 43:685-693.

15. Bombardier C, Gladman DD, Urowitz MB, Caron D, Chang CH. Derivation of the SLEDAI: a disease activity index for lupus patients: the Committee on Prognosis Studies in SLE. Arthritis Rheum. 1992; 35:630-640. [PubMed: 1599520]

16. Weening JJ, D'Agati VD, Schwartz MM, et al. The classification of glomerulonephritis in systemic lupus erythematosus revisited. J Am Soc Nephrol. 2004; 15:241-250. [PubMed: 14747370]

17. Schwartz GJ, Haycock GB, Edelmann CM Jr, Spitzer A. A simple estimate of glomerular filtration rate in children derived from body length and plasma creatinine. Pediatrics. 1976; 58:259-263. [PubMed: 951142]

18. Thierry-Palmer M, Henderson VM, Hammali RE, Cephas S, Palacios C, Martin BR, et al. Black and white female adolescents lose vitamin D metabolites into urine. Am J Med Sci. 2008; 335:278-283. [PubMed: 18414066]

19. Ruiz-Irastorza G, Egurbide MV, Olivares N, Martinez-Berriotxoa A, Aguirre C. Vitamin D deficiency in systemic lupus erythematosus: prevalence, predictors and clinical consequences. Rheumatology. 2008; 47:920-923. [PubMed: 18411213]

20. Borba VZC, Vieira JGH, Kasamatsu T, Radominski SC, Sato EI, Lazaretti-Castro M. Vitamin D deficiency in patients with active systemic lupus erythematosus. Osteoporos Int. 2009; 20:427433. [PubMed: 18600287] 
21. Wu PW, Rhew EY, Dyer AR, Dunlop DD, Langman CB, Price H, et al. 25-hydroxyvitamin D and cardiovascular risk factors in women with systemic lupus erythematosus. Arthritis Rheum. 2009; 61:1387-1395. [PubMed: 19790113]

22. Wright TB, Shults J, Leonard MB, Zemel BS, Burnham JM. Hypovitaminosis D is associated with greater body mass index and disease activity in pediatric systemic lupus erythematosus. J Peds. 2009; 155:260-265.

23. Robinson, AB.; Rabinovich, CE. Hypovitaminosis D is prevalent despite vitamin D supplementation in pediatric systemic lupus erythematosus. Abstract in: 72nd Annual Meeting of the American College of Rheumatology; 24-29 Oct 2008; San Francisco, CA.

24. Reed A, Haugen M, Pachman LM, Langman CB. Abnormalities in serum osteocalcin values in children with chronic rheumatic diseases. J Pediatr. 1990; 116:574-580. [PubMed: 2319404]

25. Saha H. Calcium and vitamin D homeostasis in patients with heavy proteinuria. Clin Nephrol. 1994; 41:290-296. [PubMed: 8050209]

26. Grymonprez A, Proesmans W, VanDyck M, Jans I, Goos G, Bouillon R. Vitamin D metabolites in childhood nephrotic syndrome. Pediatr Nephrol. 1995; 9:278-281. [PubMed: 7632510]

27. Weng FL, Shults J, Herskovitz RM, Zemel BS, Leonard MB. Vitamin D insufficiency in steroidsensitive nephrotic syndrome in remission. Pediatr Nephrol. 2005; 20:56-63. [PubMed: 15602667]

28. Sato KA, Gray RW, Lemann J. Urinary excretion of 25-hydroxyvitamin D in health and the nephrotic syndrome. J Lab Clin Med. 1982; 99:325-330. [PubMed: 6977006]

29. Freundlich M, Bourgoignie JJ, Zilleruelo G, Abitbol C, Canterbury JM, Strauss J. Calcium and vitamin D metabolism in children with nephrotic syndrome. J Pediatr. 1986; 108:383-387. [PubMed: 3485195]

30. Schmidt-Gayk H, Grawunder C, Tschope W, Schmitt W, Ritz E, Pietsch V, et al. 25-hydroxyvitamin-D in nephrotic syndrome. Lancet. 1977; 2:105-108. [PubMed: 69193]

31. Khamiseh G, Vaziri ND, Oveisi F, Ahmadnia MR, Ahmadnia L. Vitamin D absorption, plasma concentration and urinary excretion of 25-hydroxyvitamin D in nephrotic syndrome. Proc Soc Exp Biol Med. 1991; 196:210-213. [PubMed: 1990409]

32. Negri AL. Proximal tubule endocytic apparatus as the specific renal uptake mechanism for vitamin D-binding protein/25(OH)D3 complex. Nephrology (Carlton). 2006; 11:510-515. [PubMed: 17199789]

33. Nykjaer A, Dragun D, Walther D, Vorum H, Jacobsen C, Herz J, et al. An endocytic pathway essential for renal uptake and activation of the steroid 25-(OH) vitamin $\mathrm{D}_{3}$. Cell. 1999; 96:507515. [PubMed: 10052453]

34. Nykjaer A, Fyfe JC, Kozyraki R, Leheste JR, Jacobsen C, Nielsen MS, et al. Cubilin dysfunction causes abnormal metabolism of the steroid hormone $25(\mathrm{OH})$ vitamin $\mathrm{D}_{3}$. Proc Natl Acad Sci USA. 2001; 98:13895-13900. [PubMed: 11717447]

35. Ooka S, Matsui T, Nishioka K, Kato T. Autoantibodies to low-density-lipoprotein-receptor-related protein 2 (LRP2) in systemic autoimmune diseases. Arthritis Res Ther. 2003; 5:R174-R180. [PubMed: 12723989]

36. Leheste JR, Rolinski B, Vorum H, Hilpert J, Nykjaer A, Jacobsen C, et al. Megalin knockout mice as an animal model of low molecular weight proteinuria. Am J Pathol. 1999; 155:1361-1370. [PubMed: 10514418]

37. Safadi FF, Thornton P, Magiera H, Hollis BW, Gentile M, Haddad JG, et al. Osteopathy and resistance to vitamin D toxicity in mice null for vitamin D binding protein. J Clin Invest. 1999; 103:239-251. [PubMed: 9916136]

\section{List of abbreviations}

$\begin{array}{ll}\text { SLE } & \text { systemic lupus erythematosus } \\ \text { JDM } & \text { juvenile dermatomyositis } \\ \text { 25(OH)D } & \text { 25-hydroxyvitamin D } \\ \text { DBP/C } & \text { urinary vitamin D binding protein/creatinine ratio }\end{array}$




$\begin{array}{ll}\text { UP/C } & \text { spot urine protein to creatinine } \\ \text { eGFR } & \text { estimated glomerular filtration rates } \\ \text { SLEDAI } & \text { Systemic Lupus Erythematosus Disease Activity Index } \\ \text { PGA } & \text { Physician's Global Assessment }\end{array}$



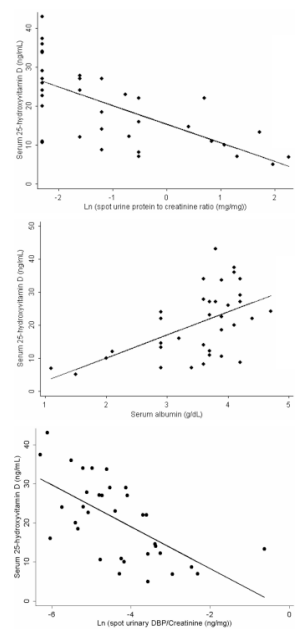

Figure 1.

Greater proteinuria and lower albumin are associated with vitamin D deficiency among subjects with SLE even with adjustment for race and vitamin D supplementation. A) Serum $25(\mathrm{OH}) \mathrm{D}$ level by log-transformation of spot urine protein to creatinine ratio among subjects with SLE* B) Serum 25(OH)D level by serum albumin among subjects with SLE** C) Serum $25(\mathrm{OH}) \mathrm{D}$ level by log transformation of urinary DBP / urinary creatinine among subjects with SLE***.

$* \mathrm{n}=36, \beta=-4.8(95 \% \mathrm{CI}-6.6,-3.0)$, adjusted $\beta=-4.1(-6.0,-2.2)$

$* * \mathrm{n}=37, \beta=7.0(95 \%$ CI 3.4, 10.7), adjusted $\beta=5.9$ (95\% CI 2.1, 9.6)

$* * * \mathrm{n}=34 \beta=-5.4(95 \% \mathrm{CI}-7.7,-3.0)$, adjusted $\beta=-4.6(95 \% \mathrm{CI}-7.1,-2.2)$ 
Table 1

Characteristics of study subjects by group

\begin{tabular}{|c|c|c|c|}
\hline & $\begin{array}{l}\text { Subjects with SLE } \\
\text { without proteinuria } \\
(\mathrm{n}=\mathbf{2 4})\end{array}$ & $\begin{array}{l}\text { Subjects with SLE } \\
\text { with proteinuria } \\
(\mathrm{n}=13)\end{array}$ & $\begin{array}{l}\text { Subjects with } \\
\text { JDM } \\
(\mathbf{n = 2 1})\end{array}$ \\
\hline Age, y (mean, SD) ${ }^{*}$ & $15.4(3.8)$ & $14.5(4.6)$ & $11.3(4.1)$ \\
\hline Range & 6 to 21 & 5 to 20 & 4 to 18 \\
\hline Duration of disease, $y$ & $2.5(2.7)$ & $3.5(3.8)$ & $3.3(3.5)$ \\
\hline Range & 0 to 12 & 0 to 12 & 0 to 12 \\
\hline Sex (\% female) & 88 & 69 & 81 \\
\hline \multicolumn{4}{|l|}{ Race $^{*}$} \\
\hline White & $4(17 \%)$ & $1(8 \%)$ & $16(76 \%)$ \\
\hline Black & $18(75 \%)$ & $9(69 \%)$ & $3(14 \%)$ \\
\hline Other/Mixed & $2(8 \%)$ & $3(23 \%)$ & $2(10 \%)$ \\
\hline BMI percentile $\geq 85(\%)$ & 50 & 54 & 33 \\
\hline Initial PGA, $\mathrm{cm}^{*}$ & $1.1(1.0)$ & $4.7(2.8)$ & $2.2(3.1)$ \\
\hline Range & 0 to 3.7 & 0 to 8.9 & 0 to 8.3 \\
\hline Initial SLEDAI* & $4.9(4.3)$ & $15.0(7.8)$ & N/A \\
\hline Range & 0 to 16 & 4 to 28 & \\
\hline \multicolumn{4}{|l|}{ Glomerulonephritis } \\
\hline III & $3(13 \%)$ & $2(15 \%)$ & N/A \\
\hline IV & $3(13 \%)$ & $4(31 \%)$ & \\
\hline $\mathrm{V}$ & $4(17 \%)$ & $2(15 \%)$ & \\
\hline III and IV & 0 & $1(8 \%)$ & \\
\hline III and V & $1(4 \%)$ & $3(23 \%)$ & \\
\hline IV and $\mathrm{V}$ & 0 & $1(8 \%)$ & \\
\hline Serum albumin $(g / d L)^{*}$ & $3.8(0.5)$ & $2.9(0.9)$ & $4.1(0.4)$ \\
\hline Range & 2.1 to 4.7 & 1.1 to 4.4 & 2.8 to 4.7 \\
\hline Serum creatinine $(\mathrm{mg} / \mathrm{dL})^{*}$ & $0.7(0.2)$ & $0.8(0.5)$ & $0.5(0.2)$ \\
\hline Range & 0.2 to 1.0 & 0.3 to 1.7 & 0.3 to 0.9 \\
\hline Estimated glomerular filtration rate & $143(49)$ & $140(77)$ & $169(49)$ \\
\hline$\left(\mathrm{ml} / \mathrm{min} / 1.73 \mathrm{~m}^{2}\right)$ & 81 to 323 & 52 to 312 & 104 to 297 \\
\hline History of photosensitivity $(\%)^{*}$ & 71 & 46 & 90 \\
\hline Active rash $(\%)^{*}$ & 25 & 23 & 57 \\
\hline Mean prednisone dose (mg/d) & $13(15)$ & $23(25)$ & $17(27)$ \\
\hline
\end{tabular}




\begin{tabular}{|c|c|c|c|}
\hline & $\begin{array}{l}\text { Subjects with SLE } \\
\text { without proteinuria } \\
(\mathrm{n}=\mathbf{2 4})\end{array}$ & $\begin{array}{l}\text { Subjects with SLE } \\
\text { with proteinuria } \\
(\mathrm{n}=13)\end{array}$ & $\begin{array}{l}\text { Subjects with } \\
\text { JDM } \\
(\mathbf{n}=\mathbf{2 1})\end{array}$ \\
\hline Plaquenil (\% taking) & 92 & 69 & 76 \\
\hline Uses sunscreen every day or most days (\%) & 70 & 31 & 62 \\
\hline Mean dietary intake of vitamin D (IU/day) & 104 & 150 & 115 \\
\hline \multicolumn{4}{|l|}{ Vitamin D supplementation } \\
\hline None & $11(48 \%)$ & $10(77 \%)$ & $14(67 \%)$ \\
\hline $400 \mathrm{IU} /$ day & $6(26 \%)$ & $2(15 \%)$ & $3(14 \%)$ \\
\hline $800 \mathrm{IU} / \mathrm{day}$ & $6(26 \%)$ & $1(8 \%)$ & $4(19 \%)$ \\
\hline \multicolumn{4}{|l|}{ Serum $25(\mathrm{OH})$ D status ${ }^{*}$} \\
\hline Mean, SD (ng/mL) & $25.0(9.2)$ & $11.9(5.6)$ & $26.2(11.0)$ \\
\hline$\leq 10 \mathrm{ng} / \mathrm{mL}$ & $1(4 \%)$ & $6(46 \%)$ & $1(5 \%)$ \\
\hline $10.1-20 \mathrm{ng} / \mathrm{mL}$ & $6(25 \%)$ & $5(39 \%)$ & $6(29 \%)$ \\
\hline $20.1-30 \mathrm{ng} / \mathrm{mL}$ & $11(46 \%)$ & $2(15 \%)$ & $7(33 \%)$ \\
\hline$>30 \mathrm{ng} / \mathrm{mL}$ & $6(25 \%)$ & $0(0 \%)$ & $7(33 \%)$ \\
\hline Urinary DBP/C, ng/mg (mean, SD) ${ }^{*}$ & $13(17)$ & $33(27)$ & $15(14)$ \\
\hline Urinary $25(\mathrm{OH}) \mathrm{D} / \mathrm{C}, \mathrm{pg} / \mathrm{mg}$ (mean, $\mathrm{SD}$ ) & $6(5)$ & $6(10)$ & $6(6)$ \\
\hline
\end{tabular}




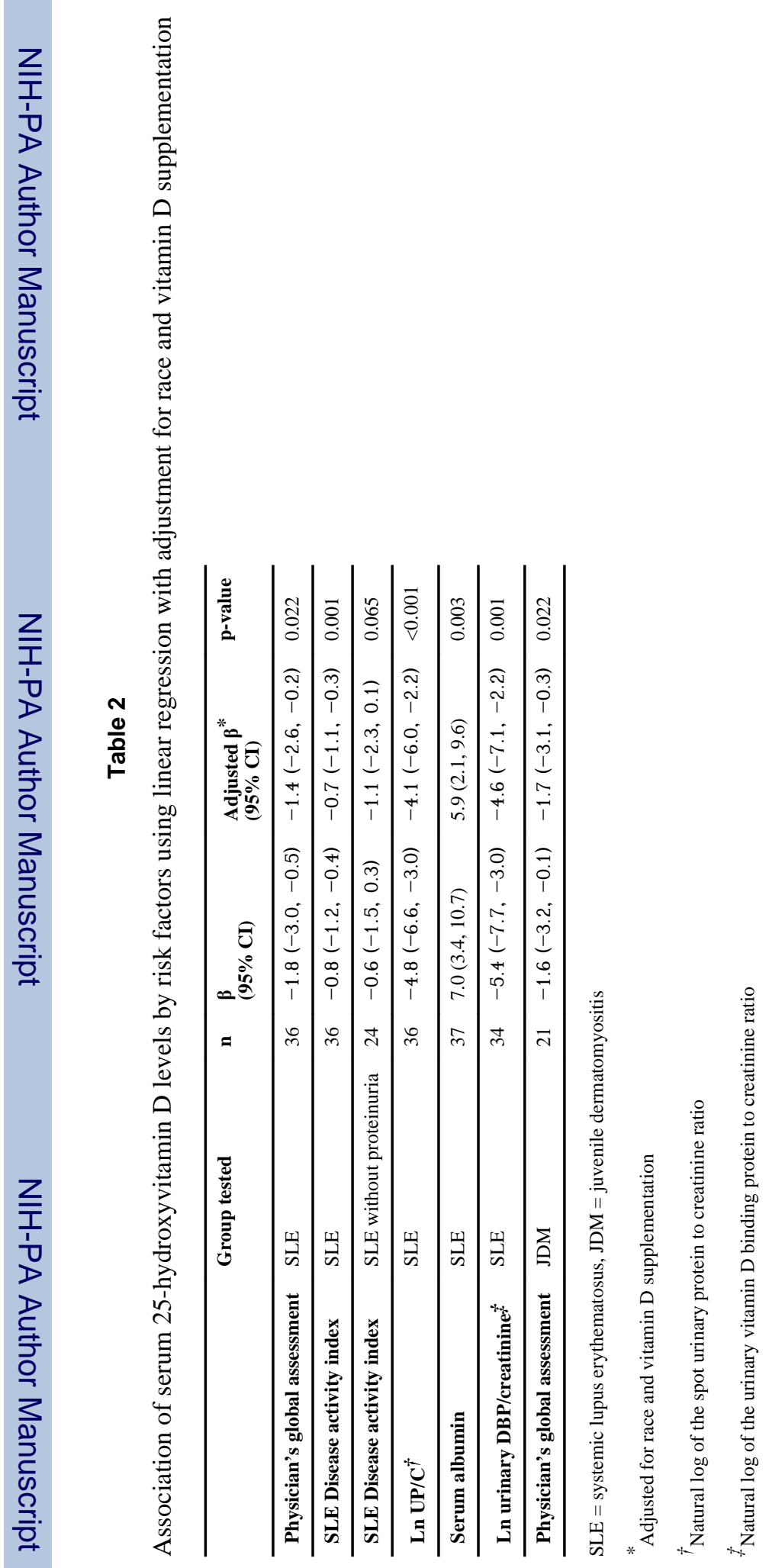

